\title{
Patriarchal Attitudes as a Catharsis for Female Self- Determination: An Analysis of Salami's Sweet Revenge
}

\author{
Maina Ouarodima, Ph.D* \\ Département d'Anglais, Université Abdou Moumouni, Niamey-Niger \\ *Corresponding Author: Maina Ouarodima, Ph.D, Département d'Anglais, Université Abdou \\ Moumouni, Niamey-Niger
}

\begin{abstract}
It is generally known and admitted that the role of any literature either oral or written is to inform, to entertain, to educate, to elucidate. It is also known that every literature is a literature of a given community at a given period. Bearing the above information in mind, then the patriarchal nature of some societies had made women such as Salami to produce literature to persuade, to convince or, to a larger extent, to change the world into a better living place. While within the literatures, many women writers depict patriarchal attitudes as obstacles to female development or self-realization; Salami, in Sweet Revenge, the Play under discussion, presents patriarchal attitudes as a route to female self-determination. Through Aisosa, the protagonist, Salami is able to show to the African women or, even better, to women the world over that male's abusive attitudes towards women is even a moving force that drives women to the peak. In the Play, Salami explores new perspectives to being a woman, within societies dominated by the ideologies of the male gender, which are worth celebrating and analyzing.
\end{abstract}

KEYWORDS: Patriarchy, gender equality, self-determination, Sweet Revenge

\section{INTRODUCTION}

It is good to put right from the onset that women writers such as Flora Nwapa, Mariama Ba, Ama Ata Aidoo, Buchi Emecheta, Zaynab Alkali, Nawal El Saadawi, Chimamanda Ngozi ect. have received much criticism, from both men and women, the world over. Not only their literary productions have been translated into various languages; but also, as said earlier, their works attract attention of critics from various perspectives. Translation, as well as criticism, gives visibility to a writer or, even better, to a writer's literary production. Christopher (1979: 26) supports that:

\begin{abstract}
Although it is usual to regard the act of criticism as inferior to the act of creation, writers and critics in Africa have acknowledged the importance of criticism in the formation of a literary tradition. The founding of the modern literary tradition has attracted a lot of attention from the literary world, and literary criticism has played an important part in stimulating this literary development.
\end{abstract}

Bearing the above quotation in mind and exploring new perspectives on African literature, there is a need to investigate on new authors, not only, to give them visibility but also and mainly to explore new trends. However,knowing that the context of situation, of the Play under analysis, is a patriarchal society, then what is patriarchy to begin with?

For Learner (1986: 216-217), patriarchy is the "manifestation and institutionalization of male dominance over women and children in the family and the extension of male dominance in society in general."Sougou (2002:13) observes in recalling Cixousthat: "the ideology of patriarchy conceives the male as active and the victor and the female as passive and the defeated"

As a result, Ouarodima (2018:179) rightly supports that as women "write in a largely patriarchal environment where the woman is not positively recognized, the African women writers have a number of perspectives to consider in the course of creating a literature that pays attention to the socio-cultural position of women".Wale (2008:20), as well, views that: "In every literary work the writer always attempts to mirror the society by making his [her] work exposit or reflect the contemporary realities of his [her] society." 
In line with the above quotation by Wale, Salami provides her readers with a testimony of a woman, Aisosa, whose deception and disillusionment, within a patriarchal system, rather than turning her into a social rebel and retaliate to her wrong doers, transform her into a strong woman and with a spirit of forgiveness and tolerance, she transforms her society. Like in the story of Shylock and Antonio in Shakespeare's comedy: The Merchant of Venice, Salami, in Sweet Revenge, does prove that mercy is better than revenge. In the Play, mercy, generosity, tolerance are presented as female characteristics and that these characteristics are worth celebrating, by both men and women. Such is the message that reverberates in the Play of Salami.

\section{THE 'VISIBLE'H ANDS OF PATRIARCHY IN THE PLAY}

The modern African literature, in general, and literature by women, in particular, convey so many patriarchal prejudices against women and Salami's Sweet Revenge is not an exception. That is, the reading of Salami'sSweet Revenge, for instance, reveals the social and cultural location of women in the patriarchal society of Nigeria. As said earlier, Ouarodima (2018:179) rightly supports that as women "write in a largely patriarchal environment where the woman is not positively recognized, the African women writers have a number of perspectives to consider in the course of creating a literature that pays attention to the socio-cultural position of women".

The aim of Salami, in portraying the visibility of patriarchy, is not only to fight the traditional view of men about women, but alsoto bring about equal rights and explain to the society, through her dramatic form of writings, the positive transformation that is needed in developing the entire society. Umelo and Sule (2005: 160) stand with the above view when they point out that one of the major achievements of women writers is to make "the man see his shortcomings, as in a mirror of life, and forcing a change of attitude that benefits both man and woman."

Thus, the section aims at discussing the impact of the patriarchal codes of conduct on women. This is because, according tothe ideology of the patriarchal society, a woman has to be dependent on men for support. Educational achievements and financial standing are the reserve of men while women must stay at home and take care of their children and their husbands as well. Finally, such ideas, embedded in men's mind, have created a very oppressive state of affairs for African women today.

In Sweet Revenge, Sota asks his wife Aisosa to resign from her position as a consultant gynecologist just to afford the children the best care they needed and this, despite her professionalism in modern medicine. For instance, Nosa, Ede's husband and a friend to Aisosa, once utters that considering Aisosa's perfect performance as a medical doctor, "she would have become the Chief Medical Director of that hospital by now" (Salami, 2004:21).To ask such a talent to stay at home or to be dormant would not favor the development of the African society. This is because each society is developed based on the action of both men and women. To consider women as just good for cooking, taking care of children and husbands is nothing else but minimizing their efforts in social development.

Also, when Sota has to move to England for a $\mathrm{PhD}$ programme in International relations, he went alone leaving his wife Aisosa and his four children. What is more, when Sota settles in England he was able to marry a wife of British origin whose name is Cheryl. The point we want to raise here is not why he marries more than one wife, as his custom requires, even his father marries up to six wives: "I am an African. My father [Sota's father] married six wives. Every father prays for his child to perform better than himself. Polygamy is no crime in Africa" (Salami, 2004:57), but the problem is that none of the wives knows that the other exists. It was through Ede, Nosa's wife, that Aisosa learns Sota's marriage with a white woman during his stay in England and that the wife has now joined him in Abuja where Sota lives as a senator. As for Cheryl, it is through Isi, the houseboy, that she learns Sota had once had a wife in Nigeria with whom he fathered four children (Salami, 2004). Such attitude by Sota clearly brings to surface patriarchal ideologies that consider women as possessions rather than full beings with feelings and emotions.

Moreover, when Sota joins Nigeria to run for a senatorial position, he has almost no women concern in his political agenda. In elucidating the position of women in the new Nigeria, Sota, in an attempt to calm down Cheryl, his British wife who wonders what would the position of women be in his political agenda?. asks her not to be too hasty, as they have just commenced. This shows that the women issues are not given prior attentions. Cheryl rationalizes and wonders: "It seems your country is made of 
only men; women are nowhere in your national agenda" (Salami, 2004:11). Sota has even been much explicit when he says: "what can a woman do in Nigerian politics?" (Salami, 2004:20). For Sota as well as for the patriarchal society, women should be kept aside as if politic is not about societal matters and that women are not part of the society.

Worst, according to Dora (1991:12), when voting time comes, a woman "waits for directives from her husband if she is married or from her father or head of the family if she still lives at home to tell her which box to throw her vote in." The question, which we are tempting to raise here, is how one can expect a free and fair election when the majority of the electorate, the women, do not know that they have a choice and, if ever they know, they are, constantly, told that they are women and the implication is that they must stay at home.

The patriarchal ideology is so strongly reflected in Sota. In fact, when Regie, his friend, joins him at his house and asks him to go to Abuja and apologize before Aisosa; his immediate reaction is: "will you get out of my house? What do you mean? You mean I should go to beg a woman to accept me back? Impossible, Regie what do you take me for, if you were in my shoes will you do that?" (Salami, 2004:76). A little further, Sota rationalizes his position: "I will rather die than accept assistance from Aisosa" (Salami, 2004: 76). In a patriarchal society, for a man to seek help from a woman is considered as a weakness. But, would Sota really accept to 'die' ? or else, would he end up asking help from Aisosa? A saying goes on that: "What goes up must come down."

To close the section, our people used to say that even silence produces echoes but not many could hear. In Sweet Revenge, Salami, implicitly, teaches her readers that the peak of patriarchal problems for women is that there is almost nowhere for women to complain their plights. Within the Play, there is no voice of political authority that may regulate Sota's abuse of power as a Senator. The justice, itself, is silent when women are abusively arrested under Sota's command. There is neither a voice of an NGO that fights injustice nor a voice of any religious authority recommending equal treatment by virtue of creation...The total absence of the above socio cultural, governmental and non-governmental institutions, in the Play, is not an attempt to criticize Salami as a female writer; rather it appreciates her feminist aesthetics, which enables her to act as a teacher and inform the readers of Sweet Revenge about what is going on in her patriarchal society of Nigeria. Seemingly, the absence translates the conspiration of silence within the patriarchal society and it is no doubt a burden to women.

\section{Disappointment as a Route to FeMALE SELF Determination}

Every person, whether a man or a woman, nourishes some expectations. To be much specific, though men and women have the same psychological basic needs of getting loved, respected and cared for; some men's attitudes in a patriarchal society, often, constitute a barrier to the fulfilment of women's expectations.

According to the Longman Dictionary of Contemporary English (1989), expectation is a "belief that something good will happen or that someone will be successful in the future." As a result, every woman in this world endeavors to achieve happiness and tranquility by struggling day and night to make her dream come true so that she may live beneath its shadow for the rest of her life. The study also establishes that disappointment is primarily experienced in a situation whereby something positive that is expected does not occur. In other words, disappointment is the result of expectations that are unfulfilled and are initially desired or hoped for.

Now, after the above clarifications and, to shift the focus to our subject matter, Salami, in Sweet Revenge, portrays a transcultural and as well as transnational problem. Sota, as said earlier, has two wives: Aisosa from Nigeria and married in Nigeria and Cheryl from England and married during his stay in England. However, what is worth mentioning here is that both women are marginalized and deceived.

Aisosa, for instance, is a typical African woman. She, courageously, takes care of the family charge during her husband's stay in England. She recalls her daily responsibility as such: “...for the past eight years[that is during her husband's stay in England] I have been a father, mother, doctor, driver, tailor, nurse, extra lesson teacher, researcher, daughter in law and all others" ( Salami, 2004:26). Despite all the above listed responsibilities, Sota's marriage to Cheryl in England remained unknown to Aisosa for long until she learns through her friend Ede rather than Sota himself. Such attitude, 
towards a woman who is legally married to him and had born four children, drives a woman to deception. Aisosa, herself, later says: "I regret resigning my job. I should have seen through him. I should never have believed him" (Salami, 2004:34). However, Aisosa transforms her disappointment into awareness to achieve greater things. At the end, not only she gets a job and is honored for her hard work, but she also raises campaign and become a senator.

Moreover, though Aisosa and Cheryl are from distinct cultural background, the two women are united by virtue of their shared gender experience. When they both come to know that Sota has deceived them by hiding his marriage, they do not only understand that each one of them is not to blame, but also and mainly they join their forces and work together in mutual understanding and pacific coexistence. This is even known to Sota who once questions: "I am now an enemy to you both?" (Salami, 2004:57). This is a clear indication that women are able to transform their disappointment into a common force that moves them from the margin to the center.

What is more, even Sota was elected Senator thanks to women's vote as Madam Power, a woman politician, explains to Aboki, a character in the Play: "Aboki, we are the ones who made your Oga [that is Sota] senator" (Salami, 2004:44). While Madam Power and women friends expect Sota to be grateful to them and acknowledge their tremendous efforts during the senatorial campaign, when they finally pay him a visit at his senatorial house, the latter, ironically, happens not to recognize them by face as we learn from Madam Power's reaction: “Me, Madam Power Power? Sota you don't know me? Well, let me introduce myself. I am Madam Power Power the leader of the women group who voted you in as senator" (Salami, 2004:45). Here too, women show ability to transform their disappointment into a moving force and eject Sota from the senatorial position. Finally, thanks to female bounding, Aisosa holds the position of Senator.

\section{SAlami's Aesthetic Strategies in Redirecting the MindDS}

In a patriarchal society, the role of literature by women is not only to inform but also to persuade by redirecting the minds of all those who nourish patriarchal ideologies into a positive consideration of women. To begin with, Christine (1980:16) observes “...majority of women assume 'silence is golden' because they lack the confidence or education to deal with male dominance." Salami's aesthetic message tends to say that the syndrome of dependency has no placein educated women and that even if fate turns out to be the case that Aisosa finds herself in, education can be a source of contentment. They can sustain their lives and that of their children without the help and support of their husbands.

Thanks to education, Aisosa who is abandoned by her husband is able to join Abuja where she finally gets a job with a salary of three hundred thousand Naira per month and not only that, she also works at the Gyny clinic (private hospital). Rightly, Umelo (2005:43) points out: “... education is not just a tool for enlightenment for the female child, but assumes the all-important role of the means of survival...'In other words, education does not only equip women to be financially independent but also it gives them awareness to go beyond the narrow confines of their own lives.For instance, Sota, who constantly complains about Aisosa by sayingthat she does not fit him as a wife, at times invites her to have sexual intercourse; but she refuses and rationalizes: "Why would I sleep with a person who despises me and does not appreciate my person?" (Salami, 2004:33-34). Even when Sota menaces Aisosa with a divorce, the latter rationalizes: "I expected it [that is the divorce] earlier than now. I saw it coming; I am not surprised at all" (Salami, 2004:27).The author tends to remind men that women, too, are human beings and as such, they need mutual respect and consideration.

Another aspect on which the writer wants to redirect the minds, in a patriarchal society, is thateven though a man is bad and it happens that a woman complains about him, nobody tends to believe her. In other words, so many wives suffer in their marital houses but not many men and, ironically, women could listen and believe their 'stories'. That is certainly why, the author engages Sota into politics to make many men and other women believe that he is bad. Madame Executive, a politician conveys the author's message when she says: "If Aisosa had come to report this case to us when it happened [that is the divorce] we would have doubted her testimony. We would have said she is not patient or submissive enough. Our experiences of last three weeks have left us without any doubt as to who Senator Sota is" (Salami, 2004:49). 
What is more, even in the process of marriage, Sota, for instance, uses his African culture, whereby he may marry as many women as possible, as a parameter to judge a foreign culture by marrying Cheryl, a woman of British origin. Thus, the author calls on our attention that it is not good to take our culture for granted and abuse or marginalize other women outside the African culture. For instance, in Britain, marrying more than one woman is forbidden. Cheryl puts a seal that: "In Britain where we married, polygamy is an offence. My father married one woman" (Salami, 2004:57).

Also, though it is known to Sota and Aisosa and to the community at large that the land where they lived belong to Sota but it is as well known to many that the house they live in was built by the money that Aisosa inherited from her parents. Yet, Sota, in an attempt to end his marital relationship with Aisosa, he asks her to vacate the house together with her four children. Worse, when Aisosa insists that the house was built by the money she inherited from her parents, Sota, sarcastically, says: "Dr. Aisosa, I am sorry I forgot about that. Please uproot your house out of my land before dawn. No matter what you do, please leave my plot of land intact" (Salami, 2004:28). A very problematic situation that recalls shylock and Antonio in Shakespeare's comedy: The Merchant of Venice.

In fact, in The Merchant of Venice, Shylock is a Jew and there were not many Jews in Elizabethan London. It was forbidden to employ Jews in administration or conduct legitimate business with them. As a result, in order to survive, they had to live on their wits. Many of them became moneylenders, lending money by interest. Antonio is also a rich man but Christian. He does not lend money by interest and as such, Shylock hates him much. Then, Bassanio, Antonio's best friend, decides to borrow money to win the hand of a beautiful wealthy heiress, Portia. The peak of the problem is that Antonio's money is tied up in his merchant ships abroad. Shy lock is asked to lend money. He agrees to lend three thousand ducats for three months but Antonio has to sign a notarized agreement such if the loan is not paid on time, Shylock had to cut off a pound of Antonio's flesh, his aim is to kill Antonio, his rival. As the story progresses, Bassanio wins Portia's hand but Antonio cannot repay the loan because of wreck. Without mercy, Shylock claims his pound of flesh. However, as the lawyer, Portia disguised, says that the bond is for a flesh but not for a single drop of blood. Shylock realizes the impossibility of having the pound of flesh without bleeding and he finally gives up his plan.

To shift to our subject matter, it is then clear that taking a house intact out of a land is as similar as cutting a pound of flesh without having a drop of blood. That is why, as in the comedy of Shakespeare, in Sweet Revenge, Aisosa also left the house to Sota: "Thanks, you can keep everything, the land and the house on it. God will avenge for me" (Salami, 2004:28). Here, the didacticism that we want to bring into focus through the Comedy of Shakespeare and the Play of Salami is that while, in The Merchant of Venice, Shylock and Antonio's case was taking to Court with a lawyer ready to defend; in Sweet Revenge, Aisosa just contents in God: "God will avenge for me" (Salami, 2004:28). The author's didacticism does seem to say that women's problems are left to themselves without having any institution ready to defend them.

Moreover, Salami drives the mind of her readers to a certain injustice within patriarchal societies that women most often face. For instance, the way that Sota divorces Aisosa is particularly and abusively strange. In fact, in almost all the traditions, a couple can divorce and at time negotiate and establish their marital life; but Sota divorces Aisosa for eternity, without giving hope that they may return to each other one day. As for religion, only Islam, to the best of my knowledge, accords to divorce a wife up to three times and after the third time, there is no more room for reconciliation until she marries another man and the latter properly divorces her; then the former husband who divorces her three times may seek her return.

The author's aesthetic preoccupation is not only that the husband divorces Aisosa for eternity, as divorce almost exists as a rule when there is incompatibility of whatever kind in a couple, not because he divorces for eternity, as Aisosa also expects the divorce, not even because he asks her to vacate the house with her four children, as Aisosa is ready for that as well; but also and mainly because the house she lives in with her four children is built with the money she inherited from her parents. The author does seem to say that a woman can leave her husband house if she is divorced but what if the wife, herself, builds the house? Salami wants the patriarchal society of Africa to find solution to such a problem that unjustly deprives women of their material possessions. Salami's strategy is, not only as Ouarodima (2019:135) points it out, to show how "a society with all its complex structures has 
conspired to subjugate and marginalize women in the schemes of events and socio-economic privileges"; but also to bring both men and women to equal consideration and mutual respect.

The last but not the least aspect to raise, in this section related to the redirecting of mind, is the political issue. In fact, patriarchal men think that women are not fit for political matters. As a result, they exclude women in their political agenda. If ever they consider them in their agenda, they are used as praise singers or simply to fill the gap on behalf of gender issues. In the community of Sweet Revenge, Salami warns us that women are not only active but, also and mainly, they can even change a man's political 'destiny' as it happens to Sota in the Play.

In fact, even the thousands of women sympathizers who voted for Sota, for the Senatorial position, voted for the sake of Aisosa who worked hard to make it possible. This is what we learn from the testimony of Nosa, a home friend of Sota:

Vote for you? No, they didn't vote for you, they voted for Aisosa. Our people have deep respect for Aisosa. They respected the way she comported herself in your absence. Some other women would have abandoned their responsibility and ran off with another man. She has been a good wife and mother, to you and your children, made a lot of sacrifices and the women wanted to reward, encourage and honour her by coming out to vote for you hopping that her lot will improve from now on (Salami, 2004:18).

The message is that if people, basically the women, voted for Aisosa; they voted because she is a good wife and a mother. For instance, even the Award that Aisosa receives in the U.S, through the tremendous efforts of Cheryl, her former British co-wife, is because she is a good mother and a good wife. Nosa, rightly,puts:"Above all you deserve the award for being the best mother and the best wife" (Salami, 2004:61).Therefore, if a man wants women to vote for him; he has to be a good husband and a good father.

Later on, Sota lost his seat at the Senate thanks to women's petition and finally Aisosa holds the position. Salami does seem to say that the life of a woman changes to the best when she leaves a bad husband and struggles for herself. This is an attempt not to keep women within the narrow confines that frustrate them. When women are united, they are able to overthrow any arrogant man like Sota. At the end of the Play, Sota becomes almost mad. Regie, Sota's friend, gives description of him to Aisosa: "The last time I met him in Benin [That is Benin State in Nigeria] he was sorry sight, leaving in someone's boy's quarters. What a pity. He said he will come to spend some time with me" (Salami, 2004:78-79). When Aisosa asked if she was repentant; Regie adds: "Well not completely, but all that pride is gone. At least he shows appreciation when you offer him assistance" (Salami, 2004:79).

Through the above quotation, the author seemingly points that certain reaction by women can positively change men's arrogant attitude. Salami presents us the episode of Sota who is arrogant, and that of Sota seeking for help from Aisosa (he says to Aisosa: "Well, please don't let the past drive you against me" (Salami, 2004:81), just to remind the patriarchal societies to consider life as a theater, everybody has his or her role to play in it.

In view of the above message, Salami, in Sweet Revenge, proves that the female state of mind is not that of revolt or retaliation but tolerance and forgiveness. When Sota asks Aisosa, his former wife whom he maltreated and who is now a Senator, for help, the latter says: "you know what Sota? Add up your monthly expenses, multiply it by twelve and I will write a cheque for you right away" (Salami, 2004:81). Mercy rather than revenge is a female quality celebrated in the Play. As a result, it is fortunate enough both men and women work together to make the world a better living place.

\section{CONCLUSION}

Using Salami's Sweet Revenge as a parameter to measure societal norms has proved that patriarchal code of conducts still exist and its several burden on women is still a reality. However, from the discussion, Salami proves enough that she is not a bench-warming spectator. As a result, in her Play, through Aisosa, her protagonist, she is able to point out that women are patient and trustworthy but their patience is not without limit. 
Through Aisosa, the author shows that when a woman gets disillusioned with man's promises, rather than complaining or retaliating, she is capable enough to change her misadventures into a moving force that enables her to be a master of her own destiny. The sum total of the messages is that instead of marginalizing women, who are also active members of the African society, it is fortunate enough both men and women work together positively for the benefit of a society without discrimination.

\section{REFERENCES}

[1] Christine. O. (1980). African Women: Their struggle for Economic Independence. London: Hutchinson \& Co. Publishers Ltd.

[2] Christopher, H. (1979). Perspectives on African Literature. London: Heinemann.

[3] Dora, O. C. (1991). Nigerian Women and the Challenges of Our Time. Lagos: Malthouse Press Limited.

[4] Lerner. G (1986). The Creation of Patriarchy. New York: Oxford University Press.

[5] Longman Dictionary of Contemporary English. (1989). New Ed. Great Britain: Richard Clay Ltd.

[6] Ouarodima, M. (2018).Women and Patriarchy: A Reading of Zaynab Alkali's The Stillborn. American Scientific Research Journal for Engineering, Technology, and Sciences (ASRJETS), Volume 43, No 1, pp 178-189.

[7] Ouarodima, M. (2019). The Cost of Being a Woman: An Analysis of Nawal El Saadawi's Woman at Point Zero. IMPACT: International Journal of Research in Humanities, Arts and Literature (IMPACT: IJRHAL), Vol. 7, Issue 4: 129-140.

[8] Salami, I. I. (2004). Sweet Revenge. Nigeria: SANIEZ Publications.

[9] Shakespeare. W. (1989).The Merchant of Venice in the Complete Works of William Shakespeare. USA: Running Press: 220-248.

[10] Umelo. O \& E. Sule. E. (2005). The Writings of Zaynab Alkali. Abuja: RON Publishers.

[11] Wale. O. S. (2008). Topics and Issues in Literature for Nigerian Undergraduates. Nigeria: Super Prints Plus.

\section{AUTHORS' BIOGRAPHY}

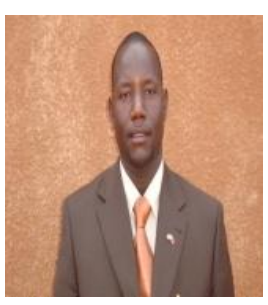

Born in Diffa - Niger Republic, after primary and secondary education in Diffa, Maina Ouarodima studied from first year to the Master programme at Abdou Moumouni University - Niger Republic and a Ph.D programme in Literature in English at UDUS /Federal Republic of Nigeria. He is currently a full time lecturer at the department of English Language and Literature at Abdou Moumouni University, Niamey-Niger. His area of research includes African Literature, African Civilization, Gender Studies, Women Studies, Comparative Studies and Aesthetics. Up to date, Maina Ouarodima attended several seminars, from within and outside Africa, and as well as published more than eight research articles in various International Journals.

Citation: Maina Ouarodima, Ph.D. "Patriarchal Attitudes as a Catharsis for Female Self-Determination: an Analysis of Salami's Sweet Revenge" International Journal on Studies in English Language and Literature (IJSELL), vol 8, no. 10, 2020, pp. 54-60. doi: https://doi.org/10.20431/2347-3134.0810006.

Copyright: (1) 2020 Authors. This is an open-access article distributed under the terms of the Creative Commons Attribution License, which permits unrestricted use, distribution, and reproduction in any medium, provided the original author and source are credited. 